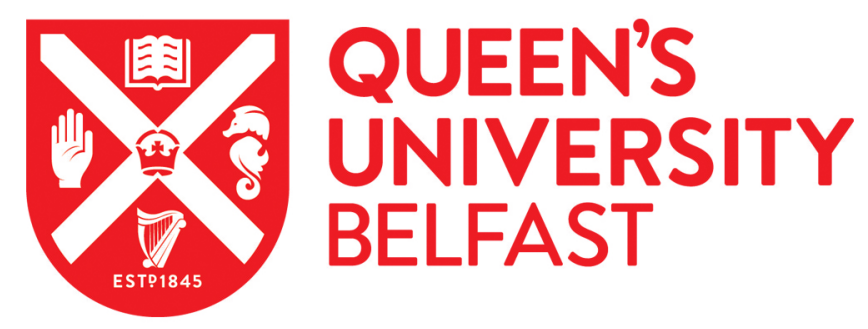

\title{
The extent of cereal cultivation among the Bronze Age to Turkic period societies of Kazakhstan determined using stable isotope analysis ofbone collagen
}

Motuzaite Matuzeviciute, G., Lightfoot, E., O'Connell, T. C., Voyakin, D., Liu, X., Loman, V., Svyatko, S., Usmanova, E., \& Jones, M. K. (2015). The extent of cereal cultivation among the Bronze Age to Turkic period societies of Kazakhstan determined using stable isotope analysis ofbone collagen. Journal of Archaeological Science, 59, 23-34. https://doi.org/10.1016/j.jas.2015.03.029

Published in:

Journal of Archaeological Science

Document Version:

Peer reviewed version

Queen's University Belfast - Research Portal:

Link to publication record in Queen's University Belfast Research Portal

\section{Publisher rights}

Copyright 2020 Elsevier.

This manuscript is distributed under a Creative Commons Attribution-NonCommercial-NoDerivs License

(https://creativecommons.org/licenses/by-nc-nd/4.0/), which permits distribution and reproduction for non-commercial purposes, provided the author and source are cited.

\section{General rights}

Copyright for the publications made accessible via the Queen's University Belfast Research Portal is retained by the author(s) and / or other copyright owners and it is a condition of accessing these publications that users recognise and abide by the legal requirements associated with these rights.

\section{Take down policy}

The Research Portal is Queen's institutional repository that provides access to Queen's research output. Every effort has been made to ensure that content in the Research Portal does not infringe any person's rights, or applicable UK laws. If you discover content in the Research Portal that you believe breaches copyright or violates any law, please contact openaccess@qub.ac.uk. 


\title{
The extent of agriculture among pastoralist societies in Kazakhstan via stable isotope analysis of bone collagen
}

\author{
G. Motuzaite Matuzeviciute ${ }^{1}$, E. Lightfoot ${ }^{2}$, T.C. O’Connell ${ }^{2}$, D. Voyakin ${ }^{3}$, X. Liu ${ }^{4}$, \\ Svyatko, $S^{5}$., Usmanova, E6 ${ }^{6}$, M. K. Jones ${ }^{2}$
}

\begin{abstract}
This paper explores the contribution of plant food to the diet of societies in Kazakhstan that are often assumed to be pastoralist. Carbon and nitrogen stable isotope analysis, together with radiocarbon dating, was carried out on human and animal bones from 24 Chalcolithic, Bronze Age, Early Iron Age, Hunic and Turkic sites across Kazakhstan. We use these data to examine dietary differences across time and space within and between populations.

Our results show that at the Bronze Age sites of mountainous southern Kazakhstan people consumed $\mathrm{C}_{4}$ plants, likely domesticated millets (Panicum miliaceum or Setaria italica) and probably cultivated $\mathrm{C}_{3}$ plants (wheat or barley). By directly dating individuals with high $\delta^{13} \mathrm{C}$ values we were able to find the earliest evidence of the consumption of large quantities of millet in Central Asia to date. By contrast, there is little input of $\mathrm{C}_{4}$ plants to diets of individuals dating to the Bronze Age from northern Kazakhstan. Stable isotope data from later periods all across the region has shown that from the Early Iron Age and continuing through to the Turkic period, $\mathrm{C}_{4}$ plants were a major component of the human food web. The wide variety of stable isotope results, both within and between contemporary sites, indicates a diversity of foodways, rather than a uniform focus on pastoralism.
\end{abstract}

\section{Introduction}

The Bronze Age in Kazakhstan has been associated with a significant transformation in the societies of the region, notably a transition from fishing and hunting to pastoralism (Kalieva and Logvin, 2011, Outram, et al., 2012, Frachetti and Benecke, 2009). Pastoral nomadism as a food-producing economy based on specialized animal husbandry has been considered the only form of human subsistence strategy in the

\footnotetext{
1 Vilnius University, History Faculty/Department of Archaeology, Universiteto 7, 01513 Vilnius; History Institute of Lithuania/Archeology Department, Kražių g. 5, LT-01108, Vilnius, Lithuania; +370 61927925, giedre.motuzaite@gmail.com

2 Department of Archaeology and Anthropology, University of Cambridge, Cambridge, CB2 3DZ, UK

3

4

5
}

6 Saraarkinsky Institute of Archaeology , Karaganda State University named after E.A/.Buketov , 28 Universitetskya St., Karaganda, 100074 Kazakhstan 
grassland during the Bronze Age (Khazanov, 1994). The presence of crops in archaeobotanical records from southern Kazakhstan, however, show that this territory constitutes a crossroads for the movement of crops that were traded and shared by mobile pastoral societies (Frachetti, 2012, Frachetti, et al., 2010, Spengler III, et al., 2014a). Western crops, such as wheat and barley, were spreading eastwards to China, while the Chinese crops, such as broomcorn or foxtail millets, arrived in Europe at some point in prehistory (Jones, et al., 2011). The pathways and the timing of the spread of Chinese crops remains open to clarification.

Whether domesticated plants in Kazakhstan were being consumed and grown or just traded during the Bronze Age is still open to debate (Ventresca Miller, et al., 2013). Based on archaeobotanical data it has been suggested that the pastoralist communities of south-eastern Kazakhstan did not consume crops as food during the Early/Middle Bronze Age but rather for trading as a part of precious goods (Frachetti, et al., 2010), During the Final Bronze Age, however, agriculture was well-established with a wide range of cereals being grown (Spengler III, et al., 2014b). While no stable isotope studies, that would allow for the detection of millet consumption, have been carried out in southern Kazakhstan, previous stable isotope studies from central and northern regions of Bronze Age Kazakhstan found very little or no cereal consumption among Bronze Age populations (Ventresca Miller, et al., 2013, Lightfoot, et al., 2014).

Stable isotope analysis uses direct and quantitative methods to investigate past human diets at the level of an individual. Using this technique it is possible to identify millet consumption in the diet of an individual through an analysis of their skeletal chemistry (see below).

This paper explores the changing role of cereals in Central Asia through isotopic analysis of individuals from across Kazakhstan from the Chalcolithic to the Turkic period. Stable isotope analysis allows us to consider the proportion of $\mathrm{C}_{4}$ plants entering the human food chain, and the analysis of animal bones allows us to consider whether those $\mathrm{C}_{4}$ plants were eaten directly by humans or if any human $\mathrm{C}_{4}$ signal was acquired through the consumption of $\mathrm{C}_{4}$-eating animals. Our primary objective here is to explore the beginning of the consumption of $\mathrm{C}_{4}$ plants in the human diet in the present territory of Kazakhstan, by looking at isotopic evidence for changing dietary patterns though time and space. In particular, we aim to ascertain whether millet was consumed on a significant scale by Bronze Age populations as a main staple food. Finally, we aim to establish whether there are regional trends, by considering the human and animal data by geographic location- north and south Kazakhstan. The major reason why these areas were chosen was the clear topographical differences between them, with the south being much hillier than the northern steppeland, making it easier for people to orientate themselves in space. Previous research has suggested that the topography played a major role in the spread of the agricultural products (cattle and cereals) in southern Kazakhstan (Frachetti, 2012).

\section{Background}

\subsection{Archaeobotanical evidence of broomcorn millet in Central Asia}

While the dominant narrative in the literature is that the Bronze Age inhabitants of Kazakhstan were pastoralist consuming mainly animal products, in recent years the evidence for plant consumption and cultivation has grown. Ethnographical and archaeological data (for example the discovery of sickles and grinding stones) suggest 
that agriculture, in particular millet (Panicum miliaceum) cultivation, has played a very important role among the populations of Central Asia from the Bronze Age onwards (Di Cosmo, 1994, Vainshtein, 1980, Dakhshleiger, 1980). This crop was, and still is, highly suitable for cultivation by semi nomadic societies in Central Asia, as it completes its life cycle in a very short period (40-90 day) (Nesbitt and Summers, 1988) and has the lowest water requirement of any cereal (Baltensperger, 2002). Gaiduchenko (Gaiduchenko, 2000, Gaiduchenko, 2002) reports the remains of "millet porridge (Panicoideae gen. sp.)" on the walls of Chalcolithic pottery from the Tersek Culture in Northern Kazakhstan, although the methodology of identification is unclear. The earliest directly dated macroremains of broomcorn millet (Panicum miliaceum) are from the Early Bronze Age (c. 2200 cal BC) human burial at Begash in southeastern Kazakhstan from a sample that also included wheat grains (Frachetti, et al., 2010). Frachetti and colleagues (Frachetti, 2012, Frachetti, et al., 2010) argue that these millet grains were exchanged as commodities and used for ritual purposes rather than as a food crop. Archaeobotanical research by Spengler and colleagues (2014) report the presence of wheat, barley and millet at Tasbas in south-eastern Kazakhstan, dated to 1450-1250 cal BC (Spengler III, et al., 2014a). Further to the southwest of Central Asia, broomcorn millet was found at Late Bronze Age Shortughai (Spengler and Willcox, 2013) and Ojakly in eastern Turkmenistan (Rouse and Cerasetti, 2014). At Ojakly, the grain was directly dated to $3370 \pm 25$ BP [OS92541] (Rouse and Cerasetti, 2014).

In neighbouring Xinjiang, China, broomcorn millet grains have been found with wheat grains in bags or small wooden vessels which were placed in the graves of Lop Nor Desert mummies, dated to the first half of the $2^{\text {nd }}$ millennium BC (Chen and Hiebert, 1995, Baumer, 2012). Further east from Xinjiang, broomcorn millet has been found at Majiayao culture sites in western Gansu province, China, dated to 27002300 BC (Dani and Masson, 1992).

From the Early Iron Age, archaeobotanical data from Kazakhstan proliferates. Recent studies in south-eastern Kazakhstan of phytoliths and carbonised plant remains have revealed the presence of a range of domesticated cereals, including free-threshing wheat, hulled and naked barley, foxtail and broomcorn millet and grapes (Chang, et al., 2003, Rosen, 2001, Spengler, et al., 2013, Rosen, et al., 2000).

\subsection{Stable isotope research in Central Asia}

The few published stable isotope studies in Kazakhstan have focused on Chalcolithic or Bronze Age sites in the northern and central territories. They indicate a Bronze Age diet based on cattle and ovicaprid meat and milk as well as freshwater fish (Privat, et al., 2006) Ventresca-Miller (2013)(Ventresca Miller, et al., 2013)O'Connell et al., 2003)(Privat, 2004). Some dietary contribution of $\mathrm{C}_{4}$ plants is detectable, with a few human outliers from the Lisakovsk and Bestomak sites with higher $\delta^{13} \mathrm{C}$ values near 18\%o (Ventresca Miller, et al., 2013). The stable isotope analysis recently conducted from the central regions of Kazakhstan report the possible consumption of $\mathrm{C}_{4}$ plants among a small part of population during the Final Bronze Age period (c. end of the $2^{\text {nd }}$-beginning of the fist millennium BC). From a slightly later period, stable isotope research in the Minusinsk basin of Russia, north of the Altai Mountains, has shown that $\mathrm{C}_{4}$ plants (presumably Asian millets) were consumed by the local inhabitants 
from c. 1400 BC onwards (Svyatko, et al., 2013). Stable isotope studies of Early Iron Age Scythian populations in the Tuva region of southern Siberia, ( $1^{\text {st }}$ century BC) have shown that $\mathrm{C}_{4}$ plants formed a significant fraction of the dietary intake (Murphy, et al., 2012). To date, no stable carbon and nitrogen isotope analyses have been published from the southern region of Kazakhstan. Therefore, despite archaeobotanical analysis of Bronze Age Begash or Early Iron Age sites in Semirechye we do not know the scale on which cultivated plants were consumed.

\subsection{Stable Isotope Technique}

The analysis of ancient diet through stable isotope analysis is based on the principle that "you are what you eat". The food that animals and humans eat is incorporated into the body tissue, and by analysing the bone chemistry we can reconstruct past human diets. For dietary analyses, the most important stable isotopes are those of carbon and nitrogen. Stable carbon isotope measurements (expressed as $\delta^{13} \mathrm{C}$ ) can distinguish between diets based on plants using two photosynthetic pathways, $\mathrm{C}_{3}$ and $\mathrm{C}_{4}$, and between diets based on marine and terrestrial foods (not relevant to this study) (Vogel and Van der Merwe, 1977, Schoeninger and DeNiro, 1984)). Plants utilising the $\mathrm{C}_{4}$ photosynthetic pathway have higher $\delta^{13} \mathrm{C}$ as they discriminate less against ${ }^{13} \mathrm{C}$ than $C_{3}$ plants (Vogel and Van der Merwe, 1977, O'Leary, 1988). As $C_{3}$ plants include most of the economic plant species in the Near East and Europe, their identification via stable isotope analysis to exact plant species is not possible, unless supported by archaeobotanical data. On the other hand, Chinese millets are particularly important for this study, as they constitute the only known $\mathrm{C}_{4}$ plants widely cultivated and consumed in Eurasian Prehistory. Whilst some $\mathrm{C}_{4}$ wild flora do grow in the steppe and deserts of Central Asia (Iacumin, et al., 2004, Winter, 1981, Makarewicz and Tuross, 2006) and potentially could enter human food chain via animal milk and meat, this is likely to be of less significance than deliberate large scale consumption of cultivated $\mathrm{C}_{4}$ plants. Thus, in conjunction with faunal isotopic analyses, long-term millet consumption by humans can be identified by stable isotope analysis, especially in territory that does not have bordering oceans.

Nitrogen isotope ratios $\left(\delta^{15} \mathrm{~N}\right)$ reflect the trophic level of animal and humans, where consumers at higher trophic levels have higher $\delta^{15} \mathrm{~N}$ values (Hedges and Reynard, 2007). Nitrogen isotope ratios of freshwater (and marine) fish are elevated compared to terrestrial mammals, influencing the isotope ratios of humans who eat fish (Richards and Hedges, 1999) (Schoeninger and DeNiro, 1984) (Schoeninger, et al., 1983). Animals grazing on saline soils also have elevated nitrogen values (Heaton, 1987, Britton, et al., 2008). High $\delta^{15} \mathrm{~N}$ values can be also caused by climatic factors (Heaton, 1987, Hollund, et al., 2010, Ambrose and Sikes, 1991). Suckling animals and humans also have enriched $\delta^{15} \mathrm{~N}$ values, because they are a trophic level higher than their mothers (Fogel, et al., 1997).

Environmental baseline $\delta^{13} \mathrm{C}$ and $\delta^{15} \mathrm{~N}$ values vary through space and time, and it is advantageous to analyse contemporary faunal samples wherever possible. Studies have shown that carbon isotope values of $\mathrm{C}_{3}$ plants can increase if plants are growing in water stressed environments (Flohr, et al., 2011). Environmental stress, such as aridity, can also increase $\delta^{15} \mathrm{~N}$ values of plants (Heaton, 1987, Schwarcz, et al., 1999). These increased isotopic values can be reflected in both animals and human bone collagen isotope results. Furthermore, the faunal carbon isotopic values in Kazakhstan 
could be elevated as a result of $\mathrm{C}_{4}$ plants in the animals' diets that today represent a minor component of the flora in Central Asia (Iacumin, et al., 2004, Winter, 1981, Makarewicz and Tuross, 2006), and thus can be used to discriminate between direct and indirect $\mathrm{C}_{4}$ input into human diet.

\section{Materials and methods}

\subsection{Isotopic Analysis}

Samples from 127 human and 109 animal bones were collected from 24 sites located across Kazakhstan (Fig. 1, SOM 1). Bone samples were obtained from three institutions: Archaeological Expertise LLC archive in Almaty, Institute of Archaeology in Karaganda and Kokshe Academy in Kokshetau. Limited faunal bones were available for analyses. Both adult and juvenile animals were sampled from the available material, as it included some juvenile bones that had been placed in human graves. Most of the human samples were collected from cranial bone, as only crania were available from the anthropological collections. Collagen was extracted following the standard method of the Dorothy Garrod Laboratory, University of Cambridge. 500 $\mathrm{mg}$ of bone were obtained from each individual sample and the surfaces of the bone pieces were then cleaned by sandblasting. Bones were demineralized in $0.5 \mathrm{M}$ aq. $\mathrm{HCl}$ at $4{ }^{\circ} \mathrm{C}$ for up to ten days, changing the acid as necessary, and after rinsing three times with distilled water, were gelatinized in an acidic solution $(\mathrm{pH} 3)$ at $75{ }^{\circ} \mathrm{C}$ for $48 \mathrm{~h}$. The liquid fraction containing the gelatanized protein was filtered off using an Ezee filter (Elkay Products) and freeze-dried. Triplicate samples of approximately 0.8 mg were used for each analysis in the Godwin Laboratory, University of Cambridge, using an automated elemental analyser (Costech, Valencia ***) coupled in continuous flow mode to a Thermo Finnigan Delta $\mathrm{V}$ isotope ratio-monitoring mass spectrometer (Bremen, Germany). Stable isotope concentrations are reported relative to the internationally defined standard VPDB for carbon, and AIR for nitrogen (Hoefs, 1997). Based on replicate analyses of international and laboratory standards, measurement errors are $<0.1 \%$ for $\delta^{13} \mathrm{C}$ values and $0.2 \%$ for $\delta^{15} \mathrm{~N}$ values.

Statistical analyses were performed using SPSS 21.0 for Mac. Samples were tested for normality using histograms and Kolmogorov-Smirnov and Shapiro-Wilk tests. The parametric data were investigated using independent samples t-tests. The nonparametric tests employed were Kruskal-Wallis tests. All statistical data are given in Table 4. Outliers are identified as samples that lie more than 1.5 times the inter quartile range (IQR) below quartile 1 (Q1) or above quartile 3 (Q3). The minimum sample size for statistical analysis was five. The statistical significance levels is considered to be $p<0.05$.

\subsection{Dating}

From those sampled for isotopic analyses, a total of 14 adult human bone samples were selected for accelerator mass spectrometer (AMS) ${ }^{14} \mathrm{C}$ dating (Table 1). All samples were prepared at the CHRONO Centre for Climate, the Environment, and Chronology, Queen's University Belfast. The prepared collagen was sealed under vacuum in quartz tubes with an excess of copper oxide $(\mathrm{CuO})$ and combusted at $850 \square \square \square$ to produce carbon dioxide $\left(\mathrm{CO}_{2}\right)$. The $\mathrm{CO}_{2}$ was converted to graphite on an 
iron catalyst following the zinc reduction method of (Slota, et al., 1987). The graphite was then pressed to produce a "target," which was then subject to AMS dating. The ${ }^{14} \mathrm{C}$ age mean and 1 standard deviation were calculated using the Libby half-life (5568 yr), following the conventions of (Stuiver and Polach, 1977). Calibration of the ${ }^{14} \mathrm{C}$ dates was undertaken using the IntCal04 calibration curve (Reimer, et al., 2004). All calibrated ${ }^{14} \mathrm{C}$ ages are given at $95.4 \%$, i.e. $2 \sigma$ probability.

\section{Results and discussion}

119 of the 167 humans (71.2\% success rate) and all 109 of animals sampled produced collagen with $\mathrm{C}: \mathrm{N}$ atomic values within the acceptable quality range of between 2.9 and 3.6 (De Niro 1985). While presenting the data we focus on the $\delta^{13} \mathrm{C}$ as the most relevant for the main questions of our paper. The statistical outputs of $\delta^{15} \mathrm{~N}$ and other statistical runs could be found in the table $\underline{4}$ and supplementary material (SOM 2, 3).

\subsection{Faunal results}

The isotopic data from all fauna are summarised in Table 2 and presented in detail in the SOM 2. The size of the faunal dataset limits the comparisons that can be made by period. For fauna from the south of Kazakhstan, there are 4 samples from the Bronze Age ( 3 ovicaprids and 1 deer), 26 samples from the Early Iron Age (14 ovicaprids, 5 cattle, 4 horses and $3 \mathrm{dogs}$ ) and 10 from the Medieval period (all ovicaprids). The faunal data from the north of Kazakhstan all date to the Late Bronze Age. In total there are 68 individuals (22 ovicaprids, 29 cattle, 14 horses, 3 dogs and 1 saiga antelope).

Although the faunal dataset from the Bronze Age period from the south is limited, some patterns can be seen in the data (Fig. 2, 3). There are no indications of $\mathrm{C}_{4}$ plant consumption in the animal samples from either southern or northern Bronze Age Kazakhstan. A comparison of Bronze Age ovicaprids from north with the ovicaprids from all periods from south Kazakhstan shows that there is no difference by region in $\delta^{13} \mathrm{C}$ values (Student's t-test, $p=0.054$ ), but there is a difference in $\delta^{15} \mathrm{~N}$ values (Student's t-test, $p=0.001$ ) (see Table 4, output 1). Also, comparison of Bronze Age ovicaprids and cattle from the north shows a difference in $\delta^{13} \mathrm{C}(p=0.005)$, but no difference in the $\delta^{15} \mathrm{~N}$ values ( $p=0.842$ ) (see Table 4, output 2), suggesting possible differences in grazing strategies.

Generally, the Iron Age animal data from south Kazakhstan show no evidence for the consumption of $\mathrm{C}_{4}$ plants (Fig. 4,5). However, two juvenile ovicaprids from Karatuma and one dog sample from Kainar Bulak site have $\delta^{13} \mathrm{C}$ values indicative of $\mathrm{C}_{4}$ consumption ( $\delta^{13} \mathrm{C}=-16.7$ and $-16.8 \%$, and $-14.5 \%$, respectively).

\subsection{Human results}

The isotope data from all humans and information on sample size and dating are summarised in Table 1, 3 and described in detail in the SOM 3. We consider the human data by geographical region (south and north) and period (Chalcolithic, Bronze Age, Early Iron Age and Medieval) (Tables 3, Fig. 2-5). 
For the south of Kazakhstan human data are available from the Bronze Age $(n=15)$, Early Iron Age $(n=68)$ and Medieval $(n=20)$ periods. The humans from the two Bronze Age sites in southern Kazakhstan (i.e. Kyzhol Bulak and Oi-Dzhailau-VII) have a mean $\delta^{13} \mathrm{C}$ value of $-16.3 \pm 1.9 \%$, and a mean $\delta^{15} \mathrm{~N}$ value of $13.0 \pm 1.6 \%$, suggesting a large input of $\mathrm{C}_{4}$ into the diet. Two individuals (GM_021 \& GM_030) with high $\delta^{13} \mathrm{C}$ from Kyzhol-Bulak have been directly dated to between 1754-1541 BC, and two with high $\delta^{13} \mathrm{C}$ (GM_26 \& GM_25) from Oi-Dzhailau-VII have been directly dated to $1608-1428$ cal BC (Fig. 6; Table 1). The human-faunal offset values (2.8\% in $\delta^{13} \mathrm{C}$ and 5.6\% in $\delta^{15} \mathrm{~N}$ ) suggest that people consumed millet directly. Comparing the two sites, we can see that while millet was consumed at both sites, the individuals at Oi-Dzhailau-VII in general consumed a higher proportion of millet (mean $\delta^{13} \mathrm{C}=-15.6 \%$ ) than those at Kyzhol-Bulak (mean $\delta^{13} \mathrm{C}=-17.8 \%$ ), although the sample size is too small for statistical analysis. Furthermore, the data suggest that southern humans had isotopically diverse diets not only between different sites but also within the same site. At Kyzhol-Bulak, three (out of four) individuals have $\delta^{15} \mathrm{~N}$ values that are clearly different from all individuals at Oi-Dzhailau-VII. These three individuals have low $\delta^{13} \mathrm{C}$ and low $\delta^{15} \mathrm{~N}$ values indicating that they relied on $\mathrm{C}_{3}$ consumption, with little or no $\mathrm{C}_{4}$ in the diet (Fig. 3, SOM 3). The earliest domesticated $\mathrm{C}_{3}$ plants (cf. bread wheat) were found together with broomcorn millet in Begash in southern Kazakhstan and dated to c. 2200 BC (Frachetti, et al., 2010). The isotopic data show that $\mathrm{C}_{4}$ consumption was a significant dietary component for a number of individuals, thus calling into question arguments that millet in Bronze Age southern Kazakhstan was not used as food, but rather exchanged as commodities and used for ritual purposes (Frachetti, 2012, Frachetti, et al., 2010).

The Early Iron Age humans from seven sites in the south of Kazakhstan have a mean $\delta^{13} \mathrm{C}$ value of $-14.7 \pm 1.7 \%$, and a mean $\delta^{15} \mathrm{~N}$ value of $12.1 \pm 1.5 \%$, suggesting a large $\mathrm{C}_{4}$ dietary intake (Table 1, 3; Fig. 4,5). Six individuals with elevated $\delta^{13} \mathrm{C}$ values were directly dated, and the dates range from 384 to 39 cal BC, confirming an Iron Age date for high $\mathrm{C}_{4}$ consumption (Table 1). It is interesting that despite the broad geography of the sites all analysed populations consumed $\mathrm{C}_{4}$ plants (Fig. 4). The archaeobotanical investigations in southern Kazakhstan support the stable isotope data, showing that the $\mathrm{C}_{4}$ plants consumed were probably broomcorn and foxtail millets (Chang, et al., 2003, Rosen, 2001, Spengler, et al., 2013, Rosen, et al., 2000). This result runs contrary to the Chinese Hanshu (translation of title?) book which covers the history of the Han Dynasty 206- BC - AD 25, where Wusun people described as nomads who "did not cultivate their land or plant trees, but were said to go in search of water and pasture for their stock animals" (Hanshu 1962: 3901-3910; (Linduff, 2014). Despite this evidence, the importance of $\mathrm{C}_{4}$ crops is indicated not only by the scale of its consumption, but also by its inferred use in ritual practices, such as seen in the Karatuma child's burial with a millet seed bedding found in kurgan 35 (Fig. 7). The isotope data demonstrate that this child also ate $\mathrm{C}_{4}$ plants in quantity $\left(\delta^{13} \mathrm{C}-14.9 ; \delta^{15} \mathrm{~N} 9.0 \%\right)$. Whilst millet was clearly an important dietary resource at this time, there are dietary differences visible between the sites (Figs. 4 and 5). A comparison of the two Early Iron Age sites with large sample sizes, Karatuma and Kainar Bulak-1, shows that there is a significant difference between them in $\delta^{13} \mathrm{C}$ (mean $\delta^{13} \mathrm{C}=-15.4 \pm 1.0 \%$ and $-12.6 \pm 1.4 \%$, respectively: $p=<0.001$ ), but not in $\delta^{15} \mathrm{~N}$ (mean $\delta^{15} \mathrm{~N}=12.3 \pm 1.6 \%$ and $12.1 \pm 1.4 \%$, respectively: $p=0.649$ ) (Table 4, output 5), suggesting that the proportion of millet in the diet varied between 
these sites. The individuals with the highest $\delta^{13} \mathrm{C}$ values at Kainar Bulak-1 (i.e. up to $10.5 \%$ ) must have consumed diets in which the majority of their protein derived from $\mathrm{C}_{4}$ plants. Such a large variation in $\delta^{13} \mathrm{C}$ values may indicate different human choice in consumption the different kinds of crops, with some of the communities eating substantially more $\mathrm{C}_{4}$ plants than other groups.

A comparison of Bronze Age humans (excluding twin infants GM_28 and GM_29) to the Early Iron Age humans from southern Kazakhstan shows no statistical difference between these populations in $\delta^{13} \mathrm{C}$ values (mean $\delta^{13} \mathrm{C}$ values of $-16.2 \pm 1.9 \%$ and $14.7 \pm 1.7 \%$ respectively: $p=0.144$ ), suggesting minimal overall change in $\mathrm{C}_{4}$ input over time (Table 4 , output 6 ).

The human samples from the four Medieval sites in southern Kazakhstan have a mean $\delta^{13} \mathrm{C}$ value of $-15.3 \pm 2.6 \%$ and a mean $\delta^{15} \mathrm{~N}$ value is $11.0 \pm 0.8 \%$ o (Table 3 ). Two individuals with elevated $\delta^{13} \mathrm{C}$ values from Temirlanovka and Butakty-1 were dated to Hunic and Turkic periods ranging from AD 140 to 1155. One sample from the Kainar Bulak-1 site also fell into the Late Hunic period dated to 126-325 BC (see Table 1; Fig. 6; Table 1). The human-faunal offset values (3.3\% in $\delta^{13} \mathrm{C}$ and $3.0 \%$ in $\left.\delta^{15} \mathrm{~N}\right)$ suggest that people consumed millet directly. There is a great variability in the $\delta^{13} \mathrm{C}$ values between site, ranging from -19.4 to $-10.0 \%$. This suggests that similarly to the Early Iron Age populations, some people ate little or no millet, while other individuals had diets that were dominated by $\mathrm{C}_{4}$ food sources. Again we can suggest that these results indicate the role of human choice in the consumption of different crops.

For the north of Kazakhstan the new human data presented in this study comes from Chalcolithic $(n=1)$ and Late Bronze Age $(n=10)$ sites. Having such a small sample size from the north, published isotope results from Lisakovs $(n=28)$, a Late Bronze site also in northern Kazakhstan, are also used for comparison (Ventresca Miller, 2013).

For the one Chalcolithic period human from the site of Karagash in north-central Kazakhstan, the $\delta^{13} \mathrm{C}$ value is $-18.2 \%$ and $\delta^{15} \mathrm{~N}$ is $12.6 \%$. These data are very similar to another northern Kazakhstan individual from the Chalcolithic settlement of Botai $\left(\delta^{13} \mathrm{C}=-18.1 \%\right.$; $\delta^{15} \mathrm{~N}=12.4 \%$ ) , who was interpreted to have eaten a diet based on $\mathrm{C}_{3}$ plants and substantial amounts of meat/dairy and fish (O'Connell et al. 2003). The radiocarbon date of the Karagash burial attributed it to the early wave of Yamnaya culture ranging from 2920-2712 cal BC (Table 1).

Eighteen individuals from nine sites in Late Bronze Age northern Kazakhstan are discussed here, including twenty-eight individuals from Lisakovsk (1860-1680 BC) published by Ventresca Miller (2013). The mean northern Bronze Age human values are $\delta^{13} \mathrm{C}=-18.7 \%$ and $\delta^{15} \mathrm{~N}=12.3 \%$. The mean $\delta^{13} \mathrm{C}$ human value is only $0.3 \%$ o higher than that of the ovicaprids and $0.6 \%$ higher than that of the cattle (Tables 2 and 3). Human collagen $\delta^{13} \mathrm{C}$ is expected to be 0 to $2 \%$ higher than the collagen values of the fauna that they consume (Bocherens and Drucker, 2003). This indicates that the human diet during the Bronze Age in northern Kazakhstan consisted of $\mathrm{C}_{3}$ plants and animals that ate $\mathrm{C}_{3}$ plants, with little or no $\mathrm{C}_{4}$ in the diet of most individuals. 
When considering the Bronze Age data by region (including that from Lisakovsk), statistical comparison indicates that Bronze Age southern and northern human samples are only marginally different in $\delta^{15} \mathrm{~N}(p=0.044$, excluding infants GM_28 and GM_29), but are significantly different in $\delta^{13} \mathrm{C}(p=0.001)$, with mean $\delta^{13} \mathrm{C}$ values from the south much higher than those from the north $\left(\delta^{13} \mathrm{C}=-16.2 \mathrm{vs}-18.7 \%\right.$ : Table 4 and 4, output 3). Given the difference in $\delta^{15} \mathrm{~N}$ values in the, admittedly limited, faunal samples it is likely that any difference in human $\delta^{15} \mathrm{~N}$ values reflects ecological differences between north and south (Table 4, output 4; Fig. 2B). The $\delta^{13} \mathrm{C}$ analyses, however, clearly show that the diet in these two regions was different, with the southern populations consuming more millet than the northern populations.

There is no Iron Age isotope data from northern Kazakhstan, but published data exist from southern Siberia that allow us to conduct a human diet comparison with our data from southern Kazakhstan. The distance between the published sites and ours is over $1000 \mathrm{~km}$, however, environmentally both southern Kazakh sites and sites in Siberia are quite similar. All of the sites are located in close proximity to mountain ranges, the southern Siberian sites being in Altai mountainous region. The stable isotope analysis on human bone collagen has shown that the Early Iron Age populations in Siberia were eating primarily $\mathrm{C}_{4}$ plants. A comparison of our data from Iron Age sites in southern Kazakhstan to that from two sites in southern Siberia, Ai-Dai and Aymyrlyg-8 (Murphy, et al., 2012) shows that there is no significant difference in $\delta^{13} \mathrm{C}(p=0.228)$ between the Iron Age populations from southern Kazakhstan and southern Siberia (mean values of -16.2 vs $-15.2 \%$ : Table 4 , output 4 ). Both sets of data are indicative of millet consumption in these two regions.

As we can see from the data presented above, a pattern of $\mathrm{C}_{4}$ plant consumption emerges in space and time. From this data, it appears that mountain slopes (higher altitude areas) have the earliest signs of crop cultivation. Previous research has shown that upland areas of the Inner Mongolian loess foothills in China were used for the earliest millet cultivation during the Neolithic period (Liu, et al., 2009). In Kazakhstan, the earliest evidence for millet consumption are also located in the southern Tien Shan Mountain region, while during the Early Iron Age millet consumption appears in the mountainous regions of Siberia. The lower altitude human populations inhabiting the steppe do not seem to have any evidence of agriculture (Figure 8). This observation, however, is based on rather small sample size and more research should be done in a future.

\section{Conclusion}

The stable isotope and radiocarbon dating results presented in this study reveal that millets became established crops in southern Kazakhstan from the Bronze Age onwards (c. 1800 cal BC), and were likely eaten directly by humans. These results constitute the earliest-to-date directly dated isotopic signals of millet consumption outside of China. The isotopic data show that $\mathrm{C}_{4}$ consumption was a significant dietary component for a number of individuals, thus calling into question arguments that millet in Bronze Age southern Kazakhstan was not used as food, but rather exchanged as commodities and used for ritual purposes (Frachetti, 2012, Frachetti, et al., 2010). Millet was not only traded but also consumed by the local population to the extent that is detectable in stable isotope analysis of human bone collagen. While it possible, indeed likely, that millet was consumed on a smaller scale at an earlier date, the early evidence for millet consumption in southern Kazakhstan suggests that this 
area represents a potential route for the spread of the millets from China, and warrants further archaeobotanical research.

This study has also shown great differences in human diet within the same period and region, even between individuals from the same site. This suggests diversity in agricultural practices with some people eating more $\mathrm{C}_{4}$ plants, and others more $\mathrm{C}_{3}$ plants. This leads to the conclusion that steppe inhabitants cannot all be put under one umbrella and called pastoralists, even when those individuals are from the same period and region. The stable isotope data presented here show that different populations and even individuals within a population engaged in very different activities during life.

\section{Acknowledgements}

The authors are grateful to the European Research Council for financial support, and to members of the FOGLIP team for useful discussions of the manuscript. We are also thankful to Catherine Kneale and James Rolfe for assistance with isotopic analysis, to archaeologists in the Kokshe academy (Kokshetav) for providing additional human and faunal samples as well as Valery Loman and Emma Usmanova from Karaganda Archaeology Institute for providing human and animal samples from the northern

Kazakhstan. GMM would like to acknowledge her Postdoctoral fellowship that is being funded by European Union Structural Funds project "Postdoctoral Fellowship Implementation in Lithuania. 


\section{References}

Kalieva, S., Logvin, V., 2011. On the Origins of Nomadism in the Asian Steppes, Archaeology, Ethnology and Anthropology of Eurasia 39, 85-93.

Outram, A.K., Kasparov, A., Stear, N.A., Varfolomeev, V., Usmanova, E., Evershed, R.P., 2012. Patterns of pastoralism in later Bronze Age Kazakhstan: new evidence from faunal and lipid residue analyses, Journal of Archaeological Science 39, 2424-2435.

Frachetti, M., Benecke, N., 2009. From sheep to (some) horses: 4500 years of herd structure at the pastoralist settlement of Begash (south-eastern Kazakhstan), Antiquity 83, 1023.

Khazanov, A.M., 1994. Nomads and the outside world, University of Wisconsin Press, Medison.

Frachetti, M.D., 2012. Multiregional Emergence of Mobile Pastoralism and Nonuniform Institutional Complexity across Eurasia, Current Anthropology 53, 2-38.

Frachetti, M.D., Spengler, R.N., Fritz, G.J., Mar'yashev, A.N., 2010. Earliest direct evidence for broomcorn millet and wheat in the central Eurasian steppe region Antiquity 84, 993-1010.

Spengler III, R.N., Frachetti, M.D., Doumani, P., Rouse, L., Cerasetti, B., Bullion, E., Mar'yashev, A.N., 2014a. Early agriculture and crop transmission among Bronze Age mobile pastoralists of Central Asia, Proceedings of the Royal Society 281, 1-7.

Jones, M., Hunt, H., Lightfoot, E., Lister, D., Liu, X., Motuzaite-Matuzeviciute, G., 2011. Food globalization in prehistory, World Archaeology 43, 665-675.

Ventresca Miller, A., Usmanova, E., Logvin, V., Kalieva, S., Shevnina, I., Logvin, A., Kolbina, A., Suslov, A., Privat, K., Haas, K., 2013. Subsistence and Social Change in Central Eurasia: Stable Isotope Analysis of Populations Spanning the Bronze Age Transition, Journal of Archaeological Science.

Spengler III, R.N., Frachetti, M.D., Domani, P.N., 2014b. Late Bronze Age agriculture at Tasbas in the Dzhungar Mountains of eastern Kazakhstan, Quaternary International.

Lightfoot, E., Motuzaite - Matuzeviciute, G., O'Connell, T., Kukushkin, I., Loman, V., Varfolomeev, V., Liu, X., Jones, M., 2014. How 'Pastoral'is Pastoralism? Dietary Diversity in Bronze Age Communities in the Central Kazakhstan Steppes, Archaeometry.

Di Cosmo, N., 1994. Ancient Inner Asian nomads: their economic basis and its significance in Chinese history, The Journal of Asian Studies 53, 10921126.

Vainshtein, S.I., 1980. Nomads of South Siberia, Cambridge University Press, Cambridge.

Dakhshleiger, G.F., 1980. Khozyaistvo Kazakhov na rubezhe XIX-XX vekov. Materialy k istoriko-etnograficheskomu atlasu, Nauka, Alma-Ata.

Nesbitt, M., Summers, G.D., 1988. Some recent discoveries of Millet (Panicum miliaceum L. and Setaria italica (L.) P. Beauv.) at excavations in Turkey and Iran, Anatolian Studies 38, 85-97. 
Baltensperger, D., 2002. Progress with proso, pearl and other millets, in: Janick, J., Whipkey, A. (Eds.), Trends in New Crops and New Uses, ASHS Press, Alexandria (VA), pp. 100-103.

Gaiduchenko, L.L., 2000. Kompozitnaya pischa i osvoenie pischevykh resursov naseleniem Uralo-Kazakhstanskikh stepei $\mathrm{v}$ epoku Neolita-Bronzy, in: Zdanovich, G.B., Zdanovich, S.Y. (Eds.), Arkheologicheskii istochnik i modelirobanie drevnikh tekhnologii: trudy muzeya-zapovernika Arkaim/Spetspipod, Arkaim, Chelyabinsk, pp. 150-169.

Gaiduchenko, L.L., 2002. Issledovanie kultury i pogrebalnogo inventarya. Pischevye prigary na sosudakh., in: Zdanovich, D.G. (Ed.), Arkaim: nekropol (po materialam kurgana 25 Bolshe-karaganskogo mogilnika). Yuzh.-Ural. kn. izd-vo, Chelyabinsk, pp. 120-128.

Spengler, R., N., Willcox, G., 2013. Archaeobotanical results from Sarazm, Tajikistan, an Early Bronze Age Settlement on the edge: Agriculture and exchange, Environmental Archaeology 18, 211-221.

Rouse, L.M., Cerasetti, B., 2014. Ojakly: A Late Bronze Age mobile pastoralist site in the Murghab Region, Turkmenistan, Journal of Field Archaeology 39, 32-50.

Chen, K.-t., Hiebert, F.T., 1995. The late prehistory of Xinjiang in relation to its neighbors, Journal of World Prehistory 9, 243-300.

Baumer, C., 2012. The History of Central Asia: The Age of the Steppe Warriors, IB Tauris.

Dani, A.H., Masson, V.M., 1992. History of civilizations of Central Asia, Unesco.

Chang, C., Benecke, N., Grigoriev, F., Rosen, A., Tourtellotte, P., 2003. Iron Age society and chronology in South-east Kazakhstan, ANTIQUITY-OXFORD77, 298-312.

Rosen, A., 2001. Phytolith evidence for agropastoral economies in the Scythian period of southern Kazakhstan, in: Meunier, J.D., Colin, F. (Eds.), The Phytoliths: Applications in Earth Science and Human History, A. A. Balkema Publisher, Leiden, pp. 183-198.

Spengler, R.N., Chang, C., Tourtellotte, P.A., 2013. Agricultural production in the Central Asian mountains: Tuzusai, Kazakhstan (410 - 150 bc), Journal of Field Archaeology 38, 68-85.

Rosen, A.M., Chang, C., Grigoriev, F.P., 2000. Palaeoenvironments and economy of Iron Age Saka-Wusun agro-pastoralists in southeastern Kazakhstan, Antiquity 74, 611-623.

Privat, K., Schneeweiß, J., Benecke, N., Vasil'ev, S.K., O'Connetl, T., Hedges, R., Craig, 0., 2006. Economy and diet at the Late Bronze Age-lron Age site of tita: Artefactual, archaeozoological and biochemical analyses, Eurasia antiqua $11,419-448$.

Privat, L.K., 2004. Palaeoeconomy of the Eurasian Steppe: Biomolecular Studies, Unpublished thesis, University of Oxford, Oxford.

Svyatko, S.V., Schulting, R.J., Mallory, J., Murphy, E.M., Reimer, P.J., Khartanovich, V.I., Chistov, Y.K., Sablin, M.V., 2013. Stable Isotope Dietary Analysis of Prehistoric Populations from the Minusinsk Basin, Southern Siberia, Russia: A new chronological framework for the introduction of millet to the eastern Eurasian steppe, Journal of Archaeological Science.

Murphy, E.M., Schulting, R., Beer, N., Chistov, Y., Kasparov, A., Pshenitsyna, M., 2012. Iron Age Pastoral Nomadism and Agriculture in the Eastern 
Eurasian Steppe: Implications from Dental Palaeopathology and Stable Carbon and Nitrogen Isotopes, Journal of Archaeological Science.

Vogel, J.C., Van der Merwe, N., 1977. Isotopic evidence for early maize cultivation in New York State, American Antiquity 42, 238-242.

Schoeninger, M.J., DeNiro, M.J., 1984. Nitrogen and carbon isotopic composition of bone collagen from marine and terrestrial animals, Geochimica et Cosmochimica Acta 48, 625-639.

O'Leary, M.H., 1988. Carbon isotopes in photosynthesis, Bioscience 38, 328-336.

Iacumin, P., Nikolaev, V., Genoni, L., Ramigni, M., Ryskov, Y.G., Longinelli, A., 2004. Stable isotope analyses of mammal skeletal remains of Holocene age from European Russia: A way to trace dietary and environmental changes, Geobios 37, 37-47.

Winter, K., 1981. C4 plants of high biomass in arid regions of Asia-occurrence of C4 photosynthesis in Chenopodiaceae and Polygonaceae from the Middle East and USSR, Oecologia 48, 100-106.

Makarewicz, C., Tuross, N., 2006. Foddering by Mongolian pastoralists is recorded in the stable carbon $(\delta 13 \mathrm{C})$ and nitrogen $(\delta 15 \mathrm{~N})$ isotopes of caprine dentinal collagen, Journal of Archaeological Science 33, 862-870.

Hedges, R.E., Reynard, L.M., 2007. Nitrogen isotopes and the trophic level of humans in archaeology, Journal of Archaeological Science 34, 1240-1251.

Richards, M.P., Hedges, R.E., 1999. Stable isotope evidence for similarities in the types of marine foods used by Late Mesolithic humans at sites along the Atlantic coast of Europe, Journal of Archaeological Science 26, 717-722.

Schoeninger, M.J., DeNiro, M.J., Tauber, H., 1983. Stable nitrogen isotope ratios of bone collagen reflect marine and terrestrial components of prehistoric human diet, Science 220, 1381-1383.

Heaton, T.H., 1987. The 15 N/14 N ratios of plants in South Africa and Namibia: relationship to climate and coastal/saline environments, Oecologia 74, 236-246.

Britton, K., Müldner, G., Bell, M., 2008. Stable isotope evidence for salt-marsh grazing in the Bronze Age Severn Estuary, UK: implications for palaeodietary analysis at coastal sites, Journal of Archaeological Science 35, 2111-2118.

Hollund, H., Higham, T., Belinskij, A., Korenevskij, S., 2010. Investigation of palaeodiet in the North Caucasus (South Russia) Bronze Age using stable isotope analysis and AMS dating of human and animal bones, Journal of Archaeological Science 37, 2971-2983.

Ambrose, S.H., Sikes, N.E., 1991. Soil carbon isotope evidence for Holocene habitat change in the Kenya Rift Valley, Science 253, 1402-1405.

Fogel, M.L., Tuross, N., Johnson, B.J., Miller, G.H., 1997. Biogeochemical record of ancient humans, Organic Geochemistry 27, 275-287.

Flohr, P., Müldner, G., Jenkins, E., 2011. Carbon stable isotope analysis of cereal remains as a way to reconstruct water availability: preliminary results, Water History 3, 121-144.

Schwarcz, H.P., Dupras, T.L., Fairgrieve, S.I., 1999. < sup $>15</$ sup $>N$ Enrichment in the Sahara: In Search of a Global Relationship, Journal of Archaeological Science 26, 629-636.

Hoefs, J., 1997. Stable isotope geochemistry, Springer-Verlag, Berlin. 
Slota, P., Jull, A.T., Linick, T., Toolin, L., 1987. Preparation of small samples for $14 \mathrm{C}$ accelerator targets by catalytic reduction of CO, Radiocarbon 29, 303306.

Stuiver, M., Polach, H.A., 1977. Discussion: reporting of C-14 data, Radiocarbon 19, 355-363.

Reimer, P., Baillie, M., Bard, E., Bayliss, A., Beck, J., Bertrand, C., Blackwell, P., Buck, C., Burr, G., Cutler, K., 2004. INTCAL 04 terrestrial radiocarbon age calibration, 0-26 cal kyr BP, Radiocarbon 46, 1029-1058.

Linduff, K.M., 2014. Immortals in a foreign land: the Kargaly diadem, Antiquity $88,160-172$.

Ventresca Miller, A., 2013. SOCIAL ORGANIZATION AND INTERACTION IN BRONZE AGE EURASIA: A Bioarchaeological and Statistical Approach to the Study of Communities, University of Pittsburgh, Pittsburgh.

Bocherens, H., Drucker, D.G., 2003. Trophic level isotopic enrichment of carbon and nitrogen in bone collagen: Case studies from recent and ancient terrestrial ecosystems, International Journal of Osteoarchaeology 13, 4653.

Liu, X., Hunt, H., Jones, M., 2009. River valleys and foothills: changing archaeological perceptions of North China's earliest farms, Antiquity 83, 82-95. 